\title{
Effect of Supplementation of Cellulolytic Enzymes on the Performance of Growing Mandya Lambs Fed with Urea Treated Farm Sugarcane Bagasse
}

\author{
G.U. Manju ${ }^{1 *}$, R.M. Sreesujatha ${ }^{2}$, S. Naveen Kumar ${ }^{3}$, K.S. Giridhar ${ }^{1}$, \\ N. Suma ${ }^{4}$ and L.R. Ananth Krishna ${ }^{5}$ \\ ${ }^{1}$ Department of Animal Nutrition, Veterinary College, KVAFSU, Shivamogga - 577204, India \\ ${ }^{2}$ Livestock Research and Information Centre (Sheep), Karnataka Veterinary Animal and \\ Fisheries Sciences University, Mandya (dst.), Karnataka -571432, India \\ ${ }^{3}$ Department of Animal Genetics and Breeding, Veterinary College, \\ Bangalore - 566024, India \\ ${ }^{4}$ Department of Animal Nutrition, Veterinary College, KVAFSU, Bangalore - 566024, India \\ ${ }^{5}$ Department of Veterinary biochemisty, Veterinary College, Shivamogga - 577204, India \\ *Corresponding author
}

\section{Keywords}

Farm sugar cane bagasse, Mandya lambs, Cellulase, Hemicellulase

Article Info

Accepted:

07 October 2019

Available Online:

10 November 2019
The present study was conducted to assess the effect of feeding farm Sugarcane bagasse (FSCB) fortified with cellulase and hemicellulase enzymes on intake, ADG and digestibility in Mandya sheep fed with 3\% urea treated finger millet (Eleucine coracona) straw as basal diet. Eighteen Mandya sheep (male lambs 6-9 month age) were selected and divided into three groups of six animals in each treatment. The trial lasted for 12 weeks. The sheep of T-1 group were fed with $3 \%$ urea treated finger millet straw and concentrated feed mixture (CFM) considered as control group. In T-2 group 50\% of finger millet straw was replaced with $0.5 \%$ cellulase and hemicellulase treated FSCB. In T-3 group $75 \%$ of Finger millet straw was replaced with $0.5 \%$ cellulase and hemicellulase treated FSCB. The mean roughage DMI was 338.15, 213.16 and $191.74 \mathrm{~g} / \mathrm{d}$ in T-1, T-2 and T-3 groups, respectively. The DMI varied significantly $(\mathrm{P}<.0001)$ between the groups. ADG was $77.14,51.91$ and $55.67 \mathrm{~g} / \mathrm{d}$ for $\mathrm{T}-1, \mathrm{~T}-2$ and $\mathrm{T}-3$ groups, respectively which was statistically non-significant. The digestibility of different nutrients varied non-significantly among the groups. Results of this study indicate that, even though supplementation of fibrolytic enzyme failed to improve the DMI of FSCB, the growth rate was not affected. This suggests that the urea treated bagasse with little supplementary feed can become a source of alternative roughage. Further study should focus on supplementation of fibrolytic enzymes with urea treatment at effective activity level to promote optimum growth performance and nutrient utilization in sheep. 


\section{Introduction}

Ruminants play an important role in the rural economy of developing country like India. Being able to digest fibrous material and byproducts, these are well suited for recycling such material and providing an additional source of income. However, the increased cost of production is causing grave concern to all those involved in this business.

This situation is further aggravated by drought conditions prevalent in one or other parts of India every year. Cereal straws form the major source of bulk and energy for ruminants in developing countries. However in the last few years, the straws have become an expensive commodity. One of the alternatives is use of agro-industrial by-products like sugarcane bagasse. In India, sugarcane production is 281.57 million metric tonnes per year (BS report, New Delhi) and for each 10 tonnes of sugarcane crushed, a sugar factory produces nearly 3 tonnes of wet bagasse.

The efficiency of utilization of crop residues like sugarcane bagasse in ruminants in very low which could be altered by a high rate and extent of digestion in rumen and better availability of microbial nutrients in the feed to support an efficient microbial growth, which could meet 80 to 90 per cent energy and 60 to 70 per cent protein needs. Strategies in improving the utilization of crop residues by rumen manipulation are maximum hydrolysis of lignocellulosic feeds by increased cleavage, through NPN substances in feed. On the other hand, protecting the true protein from microbial degradation could force the microorganisms to use NPN more efficiently (Orskov et al., 1972). According to Sarmento et al., (2001) although the cellulolytic enzymes is present in the rumen are able to hydrolyze the cellulose there is however, great difficulty to access the same points at which the cellulosic polymer rupture occurs. To improve the nutritional value of sugarcane bagasse in nature, researchers have made efforts to improve its use in animal feed (Torres et al., 2003). Because of the undesirable features present in the bagasse, its use has been improved using chemical, physical or enzymatic treatment. Torres et al., (2003) pointed out that due to low crude protein content in dry matter, approximately 90 percent of the nitrogen may be unavailable as it is associated with fiber and the acid fiber content of bagasse which has values between 58 and $62 \%$. This results in lower digestibility (25 to $30 \%$ ) and makes it a food source with low nutritional value. Urea treatment is a better option to improve the nitrogen content thereby improves the protein value of low quality roughages like sugarcane bagasse.

In addition, use of exogenous fibrolytic enzymes has shown to enhance colonization ruminal microorganisms and increase the rate of degradation in the rumen and improve the body weight gains in straw based diets (Balci et al., 2007; Singh and Das, 2009).

The utilization of sugar cane and its crop residues by different physical and biological procedures in order to increase its feeding value has determined better animal response in ruminants. The present study was conducted to ascertain the effect of supplementation of fibrolytic enzymes to farm sugarcane bagasse procured from jaggery industry on dry matter intake, digestibility and growth rate in Mandya lambs.

\section{Materials and Methods}

The present study was carried out at Livestock Research and Information Centre (Sheep), KVAFSU, Nagamangala to compare urea treated farm sugar cane bagasse fortified with cellulase and hemicellulase enzymes with urea treated finger millet (Eleucine coracona) straw. 


\section{Experimental design}

Eighteen ram lambs of six to nine months of age with uniform body weight were divided into three groups of six animals each in a completely randomized design (CRD). The sufficient farm Sugar cane bagasse (FSCB) was procured from local Jaggery manufacturing plant for the experiment. The concentrate feed mixture (CFM) sufficient for entire duration of study was prepared in a single batch and stored. Cellulase and hemicellulase enzymes were obtained from commercial manufacturer with activity of $23,00,000$ unit/g and 5,00,000 unit/g respectively. The feeding trial was carried out for 90days. The experimental animals were under uniform managemental care. The lambs were housed in a separate pen to facilitate individual feeding and watering.

The experimental diets comprised of finger millet (Eleucine coracona) straw $\left(\mathrm{T}_{1}\right), 50 \%$ of Finger millet straw was replaced with 3\% urea treated FSCB fortified with cellulase and hemicellulase at the rate of $0.5 \%\left(\mathrm{~T}_{2}\right)$ and $75 \%$ of Finger millet straw was replaced with 3\% urea treated FSCB fortified with cellulase and hemicellulase at the rate of $0.5 \%\left(\mathrm{~T}_{3}\right)$ as source of roughage.

All the sheep were fed with same concentrate feed mixture (Table 1). The diets for the experimental sheep were formulated individually to meet energy and protein requirement as per ICAR (2013) recommendations. Roughage was treated with urea at the rate of 3 per cent. The required quantity of roughage was weighed and offered to all the individual lambs at different intervals so as to ensure ad-libitum feeding. The CFM was offered at 8.00 and 16.00 hours of the day for sheep at divided doses of 125 grams per sheep per time. The free choice of clean water is made available throughout the day.

\section{Parameters studied}

\section{Dry matter intake}

Daily DMI (Dry matter intake) of forage and CFM of each experimental animal was recorded. Representative samples from fodder offered and leftover were collected daily and the DM (Dry Matter) content of both was estimated to know the actual DMI by each animal.

\section{Average daily body weight gain}

All the sheep were weighed before the commencement of experiment in the morning before having any access to either feed or water and it was taken as initial body weight (BW) of the study. The BW was recorded using digital platform weighing balance. Animals were weighed every week and average daily gain was calculated.

\section{Digestion trial and chemical analysis}

Digestion trial was conducted for six days at the end of experiment. Dung from each lamb was collected by harnessing with plastic bag tied around the lumbar region of the animal, bags were emptied 3-4 times a day and faecal pellets collected over $24 \mathrm{~h}$ from each lamb was weighed next day morning. Total collection of the day was crushed and after proper mixing $1 / 10^{\text {th }}$ of total voided faeces from each lamb was sub sampled for dry matter estimation. The sample collected over six days were pooled and grounded to obtain a particle size of $1 \mathrm{~mm}$ for further chemical analysis. For estimation of nitrogen $1 / 100^{\text {th }}$ of total voided faeces was sub sampled in a plastic air tight container of known weight with $5 \mathrm{ml}$ of 25 per cent sulphuric acid added every day as a preservative.

The samples of feed, fodder and dung were analysed for proximate constituents (AOAC, 
1995) except for the crude fibre. The fibre fractions were analysed as per the procedures described by Van soest et al., (1991).

The Farm samples of sugarcane bagasse (treated and untreated) were collected during digestibility trial of each period for analysis.

\section{Statistical analysis of data}

Data was analysed by least square method using GLM procedure using "Statistical Analysis Software" (SAS 9.3), by keeping treatment group as fixed effect. The following linear model was used for the analysis of individual parameters.

$Y_{i k}=\mu+T_{i}+e_{i k}$

Where, $Y_{i k}$ is the body weight, body weight gain, DMI and digestibility of nutrients of $n^{\text {th }}$ lamb, $\mu$ is the overall mean, $\mathrm{Ti}$ is the fixed effect of $i^{\text {th }}$ lamb in the treatment group and $e_{i k}$ is the random error to the $\mathrm{n}^{\text {th }}$ lamb.

\section{Results and Discussion}

\section{Chemical composition of experimental diet}

The chemical composition of CFM, Farm sugarcane bagasse and experimental feed is presented in Table 2. The FSCB used in this experiment contained (\%) $2.15 \mathrm{CP}, 0.61 \mathrm{EE}$, 45.35 CF, 48.35 NEF and 3.12 TA. The CP, $\mathrm{EE}$ and TA were lower than the values given by Shakweer, 2003 except CF content. Whereas, Preston (2003) obtained lower CP (1\%) and higher CF (49\%) than the values reported for FSCB in this study.

The NDF, ADF and AIA content of FSCB were 85.57, 60.24 and 1.98 per cent, respectively, which were almost comparable to the values reported in other studies (Preston, 2003; Shakweer, 2003; Kanji et al., 2006).

\section{Dry matter intake (DMI)}

The mean DMI is presented in the Table 3. The mean dry matter intake of concentrate was $231.16 \mathrm{~g}$ for all the three treatment groups. There was no left over in all the treatments. The Mean DMI of roughage was 338.15, 213.11 and $191.74 \mathrm{~g}$ for $\mathrm{T} 1, \mathrm{~T} 2$ and T3, respectively which varied significantly $(\mathrm{P}<.0001)$. There was higher roughage consumption in T1 group which were fed exclusively on Finger millet. In T2 group with 50:50 Ragi straw: FSCB the DMI was better compared to T3 with the ratio of $25: 75$. The total DMI of all the three treatment groups varied significantly $(\mathrm{P}<0.0001)$ which was recorded to be 602,477 and $456 \mathrm{~g}$ for $\mathrm{T} 1, \mathrm{~T} 2$ and T3, respectively. Sheep of all the experimental groups have not consumed sufficient dry matter intake according to the requirements of ICAR (2013) and NRC (1985) in spite of FSCB treated with $3 \%$ urea as well as CFM, however performance was not affected. The findings of this experiment was similar to Gomez et al., (2003) experiment on steers offered with star grass and sugarcane plus urea with fibrolytic enzyme and El-Kady et al., (2006) in buffalo calves fed with pearl millet straw supplemented with cellulase, xylanase, alpha-amylase and polyglacturenase (pectinase) at $0.4 \%$ of the diet, in Merino lambs given low and high forage diet with fungal enzymes (Cruywagen and Nanzyl, 2008), lambs fed with urea treated Rhodes hay supplemented with cellulolytic enzymes (Ramu, 2011), whereas addition of enzymes did not improve the palatability and intake in goats and heifers fed with Rhodes hay supplemented with cellulolytic enzymes (Siddaramanna et al., 2011).

\section{Body weight gain}

The initial, final and ADG is presented in Table 4. The initial weight of T1, T2 and T3 were recorded to be $16.93,16.37$ and 16.90 
$\mathrm{kg}$, respectively which was statistically nonsignificant. Final weight was 19.63, 18.18 and $18.88 \mathrm{~kg}$ for $\mathrm{T} 1, \mathrm{~T} 2$ and $\mathrm{T} 3$, respectively. Weekly ADG was calculated and the mean ADG during the trial period was $77.14,51.91$ and $55.67 \mathrm{~g}$ for $\mathrm{T} 1, \mathrm{~T} 2$ and $\mathrm{T} 3$, respectively which was statistically non- significant but numerically $\mathrm{T} 1$ had better ADG compared to other two treatment groups. Whereas, Balci et al., (2007) reported significantly higher $(p \leq 0.05)$ body weight gain in steers fed with enzyme treated wheat straw for a period of 80 Days.

Table.1 Ingredient Composition (\% M/M) of concentrate feed mixture fed to experimental sheep

\begin{tabular}{|c|c|c|}
\hline SL No. & Ingredient & Level of inclusion (\%) \\
\hline 1 & Maize & 41 \\
\hline 2 & Soybean meal & 17 \\
\hline 3 & Wheat bran & 38 \\
\hline 5 & Mineral mixture & 2.0 \\
\hline 7 & Salt & 2.0 \\
\hline & Total & $\mathbf{1 0 0}$ \\
\hline
\end{tabular}

Note: The mineral mixture contained Calcium- $22 \%$, Phosphorus- $9 \%$, Manganese sulphate- $0.2 \%$, Potassium iodide- $0.02 \%$, ferrous sulphate- $0.6 \%$, Copper sulphate- $0.5 \%$, Cobalt sulphate- $0.02 \%$, Zinc sulphate- $0.2 \%$, Selenium- $0.02 \mathrm{mcg}$ and Yeast- q.s.

Table.2 Chemical composition of CFM, FSCB and experimental feed (\% DMB)

\begin{tabular}{|c|c|c|c|c|c|}
\hline Parameters & Concentrates & FSCB & T1 & T2 & T3 \\
\hline OM & 90.5 & 96.88 & 97.12 & 96.89 & 97.32 \\
\hline CP & 17.2 & 2.15 & 6.15 & 5.84 & 5.54 \\
\hline EE & 2.34 & 0.61 & 0.64 & 0.53 & 0.55 \\
\hline CF & 6.9 & 45.35 & 42.53 & 43.89 & 48.63 \\
\hline NFE & 63.36 & 48.77 & 47.8 & 46.63 & 42.6 \\
\hline TA & 10.2 & 3.12 & 2.88 & 3.11 & 2.68 \\
\hline AIA & $1.68 \pm 0.02$ & $1.98 \pm 1.06$ & $1.60 \pm 0.04$ & $1.96 \pm 1.04$ & $2.45 \pm 1.05$ \\
\hline NDF & $31.33 \pm 0.40$ & $85.57 \pm 1.65$ & $85.52 \pm 2.58$ & $86.81 \pm 1.95$ & $86.67 \pm 2.05$ \\
\hline ADF & $12.38 \pm 0.16$ & $60.24 \pm 1.82$ & $62.00 \pm 1.93$ & $61.17 \pm 2.88$ & $64.68 \pm 1.59$ \\
\hline
\end{tabular}

Table.3 Mean dry matter intake (g/d) of experimental sheep

\begin{tabular}{|c|c|c|c|c|}
\hline Parameter & T1 & T2 & T3 & $\begin{array}{c}\text { P } \\
\text { Value }\end{array}$ \\
\hline Concentrates (g/day) & 231.16 & 231.16 & 231.16 & \\
\hline Roughage DMI (g/day) & $338.15 \pm 3.15^{\mathrm{a}}$ & $213.11 \pm 2.49^{\mathrm{b}}$ & $191.74 \pm 3.05^{\mathrm{c}}$ & $<.0001$ \\
\hline & $(264)$ & $(264)$ & $(264)$ & \\
\hline Total DMI (g/day) & $\begin{array}{c}602.87 \pm 7.19^{\mathrm{a}} \\
(90)\end{array}$ & $\begin{array}{c}477.83 \pm 4.97^{\mathrm{b}} \\
(90)\end{array}$ & $\begin{array}{c}456.46 \pm 4.80^{\mathrm{c}} \\
(90)\end{array}$ & $<.0001$ \\
\hline
\end{tabular}


Table.4 Initial, final weight $(\mathrm{kg})$ and gain $(\mathrm{g} / \mathrm{d})$ of experimental sheep

\begin{tabular}{|c|c|c|c|c|}
\hline Parameters & T1 & $\mathbf{T 2}$ & T3 & $P$ value \\
\hline Initial Weight (kg) & $\begin{array}{c}16.93 \pm 0.65 \\
(6)\end{array}$ & $\begin{array}{c}16.37 \pm 0.54 \\
(6)\end{array}$ & $\begin{array}{c}16.90 \pm 0.38 \\
(6)\end{array}$ & 0.7072 \\
\hline Final Weight(kg) & $\begin{array}{c}19.63 \pm 0.24^{\mathrm{a}} \\
(6)\end{array}$ & $\begin{array}{c}18.18 \pm 0.46^{b} \\
(6)\end{array}$ & $\begin{array}{c}18.88 \pm 0.23^{\mathrm{ab}} \\
\text { (6) }\end{array}$ & 0.0234 \\
\hline $\operatorname{ADG}(g)$ & $\begin{array}{c}77.14 \pm 13.50 \\
(6)\end{array}$ & $\begin{array}{c}51.91 \pm 3.86 \\
(6)\end{array}$ & $\begin{array}{c}55.67 \pm 6.78 \\
(6)\end{array}$ & 0.1432 \\
\hline
\end{tabular}

Table.5 Mean digestibility of nutrients (\%) of experimental sheep

\begin{tabular}{|c|c|c|c|c|}
\hline Digestibility (\%) & T1 & T2 & T3 & $\begin{array}{c}\text { Treatment } \\
\text { effect }\end{array}$ \\
\hline DM & $59.18 \pm 1.05$ & $58.72 \pm 1.94$ & $58.03 \pm 1.23$ & NS \\
\hline OM & $61.28 \pm 1.10$ & $61.03 \pm 0.74$ & $59.11 \pm 1.21$ & NS \\
\hline CP & $74.21 \pm 2.81$ & $73.51 \pm 1.02$ & $70.25 \pm 1.43$ & NS \\
\hline EE & $71.81 \pm 1.16$ & $69.71 \pm 2.11$ & $68.62 \pm 1.10$ & NS \\
\hline CF & $55.27 \pm 0.77$ & $53.58 \pm 2.17$ & $51.48 \pm 1.01$ & NS \\
\hline NFE & $61.41 \pm 1.60$ & $59.92 \pm 1.13$ & $57.15 \pm 0.42$ & NS \\
\hline NDF & $49.11 \pm 2.21$ & $47.64 \pm 1.18$ & $46.08 \pm 1.21$ & NS \\
\hline ADF & $36.91 \pm 1.31$ & $40.15 \pm 1.00$ & $40.54 \pm 1.12$ & NS \\
\hline
\end{tabular}

Note: NS- non-significant.

\section{Digestibility of nutrients}

The mean digestibilities of nutrients of experimental sheep are given in Table 5. The mean apparent digestibility (\%) of nutrients for T-1,T-2 and T-3 groups with respect to DM, OM, CP, EE, CF, NFE, NDF and ADF were $59.18,58.72$ and $58.03 ; 61.28,61.03$ and $59.11 ; 74.21,73.51$ and $70.25 ; 71.81,69.71$ and $68.62 ; 55.27,53.58$ and $51.48 ; 61.41,59.92$ and $57.15 ; 49.11,47.64$ and $46.08 ; 36.91$, 40.15 and 40.54 , respectively. The differences among the groups with respect to nutrient digestibility were non-significant. However, additions of enzymes have improved the digestibility of the FSCB on par with the finger millet. This marginal improvement in the utilization of nutrients over basal diet (3\% urea treated finger millet) without enzymes is a indicative of further chances of improving the utilization of nutrients in FSCB by optimising the level of cellulase and hemicellulase. Similar results were also obtained when Nali rams fed solely with $4 \%$ urea treated jowar straw (Sheela et al., 2004). An addition of fibrolytic enzymes to some of the crop residues like wheat straw fed to sheep (Pinos-Rodriguez et al., 2007), oat hay fed to goats (Singh and Das, 2008) and Rhodes hay fed to lambs (Ramu, 2011) showed significant improvement in the digestibility of nutrients.

Supplementation of fibrolytic enzymes to urea treated FSCB did not improved palatability and dry matter intake in Mandya lambs however, the performance of the lambs were analogous to conventional roughages.

This suggests that the urea treated bagasse with little supplementary feed can become a source of alternative roughage. Further study should focus on supplementation of fibrolytic enzymes with urea treatment at effective activity level to promote optimum growth performance and nutrient utilization in sheep. 


\section{References}

A.O.A.C, 1995.Official Methods of Analysis, $16^{\text {th }}$ Ed. Association of Official. Analytical Chemists, Washington, D.C, USA.

Balci, F., Dikmen, S., Gencoglu, H., Orman, A., Turkmen, I.I. and Biricik, H. 2007.The effect of fibrolytic exogenous enzyme on fattening performance of steers. Bulgarian Journal of Veterinary Medicine. 10(2): 113.

Beauchemin, K.A., olombatto, D., Morgavi, D. P. and Yang, W. Z. 2003. Use of exogenous fibrolytic enzymes to improve feed utilization by ruminants. Journal of Animal Science. 81(2): E37E47.

Cruywagen, C.W. and Nanzyl, W.H. 2008. Effects of fungal enzyme cocktail treatment of high and low forage diet on lamb growth. Animal Feed Science Technology. 145: 151-158.

Elkady, R.I., Awadlla, I.M., Mohmed, M.I., Fadel, M. and Abdelrahman, H.H. 2006. Effect of exogenous enzymes on the growth performance and digestibility of growing buffalo calves. International Journal of Agriculture and Biology. 8:354-359.

Gomez Vazquez., Perez, J., Mendoza. G.D., Aranda, E. and Hernadez,.A. 2003. Fibrolytic exogenous enzymes improve performance in steers fed sugarcane and starrgrass. Livestock Production Science.82:249-254.

Kanji Okano., Yuko Iida., Muhammad Samsuri., Bambang Prasetya., Tomoya Usagawa and Takashi Watanabe. 2006. Comparison of in vitro digestibility and chemical composition among sugarcane bagasse treated by four white-rot fungi. Animal Science Journal. 77: 308-313.
El-Kady, R, I., Awadalla, I, M., Mohammad, M, I., Fadel, M. and Abd El-Rahman, H. H. 2006. Effect of exogenous enzyes on the growth performance and digestibility of growing buffalo calves. International Journal of Agriculture and Biology. 8: 354-359.

Orskov, E.R., Fraser, C. and Mcdonald.I. 1972. Digestion of concentrates in sheep. The effects of urea on digestion and nitrogen retention and growth in young lambs. Brazilian Journal of Nutrition. 27:491-500.

Pinos-Rodriguez, J. M., Moreno, R., Gonzalez, S. S., Robinson, P. H., Mendoza, G., Alvarez, G. 2007. Effects of exogenous fibrolytic enzymes on ruminal fermentation and digestibility of mixed rations fed to lambs. Animal Feed Science Technology.142: 210-219.

Preston, R. L. 2003. Feed composition guide. Texas Techn. Univ., Columbia Court, Pagosa Springs, CO., U.S.A,pp. 191.

Ramu, K.C. 2011. Effect of supplementation of surfactant and cellulolytic enzymes on the performance of growing lambs fed urea treated Rhodes. M.V.Sc.thesis. KVAFSU, Bidar, India.

S.A.S. 2013. User's Guide, Release 9.3.1. SAS Institute Inc., SAS/STAT ${ }^{\mathrm{TM}}$, Statistical Analysis System Institute Inc., Cary, NC.

Sarmento P., Garcia R., Pires A. J. V. and Nascimento A. S. 2001. Soybean grain as urease source for the sugarcane bagasse ammoniation with urea. Scientia Agrícola. 58(2):223-227.

Siddaramanna., Gideon Glori Doss,R., Chanrapal Singh,K., Krishnamoorthy, U., Bhaskaran,R., Nagaraja,C.S. and Prabhu,T.M. 2011.Effect of supplementation of surfactant and cellulolytic enzymes on the performance of growing crossbred cattle fed with urea treated Rhodes 
Hay (Chloris gayana). Indian Journal of Animal Nutrition 28(4): 396.

Singh, K.K. and Das, M.M. 2008. Effect of fibrolytic enzyme treated oat hay on rumen fermentation and nutrient utilization in calves. Indian Veterinary Journal. 85: 1070-1072.

Shakweer, I. M. E. 2003. Effect of biological treatments of rice straw and sugarcane bagasse on their digestibility, nutritive value, ruminal activity and some blood parameters in rams. Egyptian Journal of Nutrition and Feeds. 6: 925-940.

Sheela, C., Mathur, O.P. and Ajay singh. 2004. Nutritional evaluation of urea treated millet stalks in rams. Indian Journal of Animal Nutrition. 2: 115117.

Torres L.B., Ferreira M.A., Véras A.S.C., Melo A.A.S. and Andrade D.K.B. 2003. Sugar cane bagasse and urea as replacement of soybean meal in the growing dairy cattle diets. R. Bras. Zootec. 32(3): 760-767.

Van-soest, P.J. Robertson, J.B. and Lewis, B.A. 1991. Methods of dietary fibre, neutral detergent fibre, and nonstarch polysacharides in relation to animal nutrition. Journal of Dairy Science. 74: 3583-3597.

\section{How to cite this article:}

Manju, G.U., R.M. Sreesujatha, S. Naveen Kumar, K.S. Giridhar, N. Suma and Ananth Krishna, L.R. 2019. Effect of Supplementation of Cellulolytic Enzymes on the Performance of Growing Mandya Lambs Fed with Urea Treated Farm Sugarcane Bagasse. Int.J.Curr.Microbiol.App.Sci. 8(11): 502-509. doi: https://doi.org/10.20546/ijcmas.2019.811.061 